\title{
INFLECTION AND GOVERNMENT IN ARABIC ACCORDING TO SPANISH MISSIONARY GRAMMARIANS FROM DAMASCUS (XVIIITH CENTURY): GRAMMARS AT THE CROSSROADS OF TWO SYSTEMS?
}

\author{
Otto Zwartjes \\ University of Amsterdam, NIAS
}

\section{Introduction}

Grammars of Hebrew written in Europe in the Renaissance by Christians could benefit from the Hebrew grammatical tradition. Johannes Reuchlin (1455-1522) quotes in his De rudimentis hebraicis (1506) Priscian and 'Rabbi David' (i.e. Qimhi) as well (Law 2002, 247-248). In grammars of Sanskrit written in Europe we see also that the framework of grammatical description has been derived from the Indian grammatical tradition. The German Jesuit Heinrich Roth (1620-1668), as Hauschild (1988, 13-14) observes, 'uses with perfect familiarity the technical terms of Indian grammar [...] Roth stands entirely within the Indian grammatical tradition, and probably he used the practical grammar of Anubhûti Svarûpâcârya, called the Sârasvata Vyâkarana, which was in general circulation in Hindustân, Bihâr and Benares. [...]. Another candidate, though a less likely one, would be the grammar called Mugdhabodha, which was composed in the second half of the 13th century by Vopadeva, but the usage of which was more common

\footnotetext{
1 This article is an elaborated version of paper delivered at the IIIrd International Conference on Missionary Linguistics, Hong Kong and Macau, 12th-15th March 2005. The organization of the conference and participation in Hong Kong has been made possible by financial support of the Norwegian Research Council (Norges Forskingsråd) and the Language Centre of the Hong Kong University of Science and Technology. I have to acknowledge Kees Versteegh who inspired me to do research in the field of the History of Linguistics and particularly Michael Carter for his valuable corrections and suggestions. Thanks to my colleague Maria Cândida Barros, I came across the reference to the grammar of Lucas Caballero. Research has been made possible by the Radboud University (TCMO) where my 2 research on Pedro de Alcalá started. I continued this research topic at the University of Oslo, supported by the NFR-project OsProMil (Oslo Project on Missionary Linguistics). I am grateful to the Rogge Library (Strängnäs) for the reproduction of the MS. I gladly acknowledge Pierre Winkler for his translations from Latin.
}

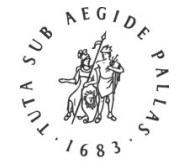


in Bengal... The work of Roth was a 'masterpiece', which does not differ considerably from current grammars, which similarly depend on the linguistic achievements of India's own grammatical tradition' (Hauschild 1988, 13-14). In the grammars of Japanese written by the Portuguese Jesuit João Rodrigues (1561-1634), particularly in his description of particles and verbal endings, we can also find information concerning the study of 'tenifa' or 'tenivofa' (the study of particles and verbal endings) from contemporary Japanese scholars (Maruyama 2004, 155). As has been demonstrated by Gregory James (2007), some missionaries describing the Tamil language, such as Bartholomäus Ziegenbalg (16821719), were familiar with some ancient Tamil works on grammar. These missionaries worked under favourable conditions compared to their colleagues who described languages, particularly Amerindian and Austronesian, without any written tradition or an adequate 'indigenous' grammatical framework they could rely on.

The use of Arabic grammatical terms in the first grammar written in Europe of vernacular Arabic, the Arte para ligeramente saber la lengua arabiga (1505) of Pedro de Alcalá (Order of St. Jerome) has been the subject of an article written by William Cowan (1981). In de Alcalás grammar, some technical terms were incorporated in the descriptive framework, including terms such as damir, temiz, masdar, amr and xucla. In this article, Spanish grammars of Arabic-vernacular and classical-written by Franciscans in Damascus and completed, copied, or printed in Spain in the 18th century occupy our attention, particularly the grammars of Francisco Caballero and Juan de la Encarnación (18th century) and Francisco Cañes (1730-1795). Of the first we have an unpublished manuscript, which has escaped the attention of researchers until today, ${ }^{2}$ and of the second a printed work has been conserved,

\footnotetext{
2 Bibliographical information concerning Francisco Cañes can be found in Schnurrer $(1811,79$, no. 113) BICRES III, and in Monroe (1970) we find some historical background. However Cañes is not mentioned by Fück (1955), Dannenfeldt (1955), and Killean (1984) and particularly the grammar of Caballero has been neglected by all.

After a century-long period of silence and total neglect, an important monograph on Bernardino González appeared recently, together with a facsimile edition of the dictionary (Intérprete arábico) and his grammar (Epítome) (Lourido Díaz 2005), not long after this paper had been delivered in Hong Kong. When the proofs were almost ready for publication, I received a copy of this monograph, courtesy of Emilio Ridruejo. Lourido Díaz (2005, I, 21-22) had traced seven manuscripts of the dictionary, and six copies of Epítome de la gramática árabe made by Bernardino González' pupils, probably for their own use. One copy was completed by Blas Francisco de Salamanca in 1704, the second by Lucas Caballero and Juan de la Encarnación between 1709 and 1710, the so-called Tingstadius copy. Two copies were compiled in 1719, one from the El Escorial
} 
studied sporadically by dialectologists describing the urban colloquial Arabic of Damascus (Lentin 1997), but which also escaped the attention of researchers working in the field of the history of linguistics. In the Damascene Franciscan tradition, the authors used a great number of Arabic grammatical terms, adapted in a hispanicised form, which substituted, accompanied or sometimes superseded Latin terminology: examples are: 'arabicación' ('i rāb), 'moziones' (harakāt) or the 'partículas nasbantes, chazmantes and charrantes.' Obviously, these Franciscan authors were informed by the Maronite Christians, but in the prologue of the grammar of Francisco Cañes, we read that Spanish Franciscans not only were familiar with the work of Pedro de Alcalá, but also that they were inspired by north-European grammars and dictionaries of Arabic, such as the famous grammar written in Latin by Thomas van Erpen (= Erpenius 1585-1624) and lexicographical work of Jacob Golius

and the other from the University of Valencia and two further anonymous and undated manuscripts from the Real Academia de la Historia. Lourido Díaz states that all these works were calques of that of Bernardino González (Lourido Díaz 2005, I, 13). All the Latin grammars analysed in this article are also listed in two footnotes by Lourido Díaz (2005, I, 130 and 135) but very little importance is given to the influence of these on the grammatical tradition of the Franciscans linked to Damascus. After having consulted all these Latin grammars, we have come to the conclusion that the Spanish grammars of Arabic completed by Franciscans in Damascus or in Spain were heavily inspired by the Latin grammars, and in some cases they are Spanish calques, or translations of the Latin examples. This is particularly evident in the grammatical examples and the use of literally almost the same 'orientalising' terminology, inherited from the Arabic tradition. Thanks to the evidence of Lourido Díaz' study, a direct link between the Franciscans in Damascus and Spain and the Holy Congregation of the Propaganda Fide and the San Pietro di Montorio can now be confirmed. Juan de la Encarnación learned Arabic from his teacher Lucas Caballero, a pupil of Bernardino González. The latter, in his turn, was a pupil of the Italian Fray Bonaventura da Molazzana, who taught at the San Pietro di Montorio and who arrived in Seville in 1693. It is known that the grammars and dictionaries used at the San Pietro di Montorio were those of Dominicus Germanus and Philip Guadagnoli, among others, and it is thus probable that Bernardino González had direct access to the 'Italian' grammatical tradition. It is also important for the purposes of this article to know that the work of Bernardino González was also obligatory in the curriculum for Spanish and Portuguese missionaries (Lourido Díaz 2005, I, 34). Morevoer, the Portuguese Arabist de Sousa was born in Damascus, so all these grammars are thus linked and use common sources. Germanus of Silesia was educated in the Holy Land, and was later an Arabic instructor in the El Escorial Monastery in Spain. Although Lourido Díaz' monograph is without any doubt extremely important for all those interested in the bio-bibliographical data related to Bernardino González and his successors, little importance is given in it to the influence of Latin sources and almost nothing is said about possible Arabic sources, the significance of these works from the perspective of the history of linguistics or the history of Arabic. Are these grammars to be considered as key creative productions on the part of Spanish missionaries, or are they nothing more than a chain in a long tradition? In the future we hope to give an answer to this question. 
(1596-1667). Other sources mentioned by Cañes are the grammars of Felipe Guadañoli, ${ }^{3}$ Antonio de Aguila, ${ }^{4}$ Agapito de Valle Flammarum, ${ }^{5}$ and Francisco Gonzalez, ${ }^{6}$ and the Franciscan grammarian also informs us that he used a "considerable number of manuscripts," without specifying which sources these were. In Renaissance grammars, we find usually two subdisciplines in syntax. In the Spanish tradition, syntax, often called 'construcción', can be subdivided in 'construcción de régimen' and 'construcción de concordancia' and Francisco Cañes does not form an exception. In this article we concentrate on the first and we particularly attempt to analyze how the concept of 'amil (often translated as 'governor') has been incorporated into this model. The subject of concord (agreement) has been analysed in Zwartjes (2007). The use of Arabic grammatical terms in these grammars will be analyzed, and we will concentrate on the following questions related to morphosyntax:

- Which Arabic grammatical terms are used in these Spanish grammars particularly in the sections dedicated to inflection and agreement?

- What did they mean and why did they use them?

- Which sources could they have used?

\section{The grammar and dictionary of Arabic of Pedro de Alcalá}

As we all know, Arabic speaking communities are diglossic. Pedro de Alcalás dictionary and grammar of Granadan Arabic is obviously a description of colloquial Arabic. His purpose was to teach the 'ordinary people' ('los populares') and not the language of 'the wise' ('alfaquies'). The aims to compose his dictionary are also slightly different if we compare them to other missionary dictionaries in the New World, where missionary composed dictionaries for their own use and for the novices from the Old World. As we can read in the prologue to his dictionary, Pedro de Alcalá wrote his dictionary not only for the Old Christians who wanted to learn Arabic, but also for the New Christians. ${ }^{7}$

\footnotetext{
${ }^{3}$ Schnurrer $(1811,47$, no. 72$)$.

${ }^{4}$ Antonius Ab Aquila (Schnurrer 1811, 50, no. 78).

${ }^{5}$ Schnurrer $(1811,59$, no. 85), or Agapito à Valle Flemmarum (da Val di Fiemme).

${ }^{6}$ I have not identified this author yet, but this could possibly be Bernardino González, as Lourido Díaz suggests (2005).

7 "Ca assi como los aljamiados (o cristianos viejos) pueden por esta obra saber el arauia, viniendo del romance al arauia: assi los arauigos (o nueuos cristianos), sabiendo leer la
} 
As has been demonstrated in recent research, mainly from Federico Corriente (1988), it is true that the language described is predominantly colloquial, ${ }^{8}$ but at the same time it is also obvious that there is some interference between the colloquial and the classical registers. The main objective of all missionary grammars is practical: the teaching of a certain language. Nevertheless, missionary works can be predominantly didactic, showing many paradigms with few explanations and linguistic theory, while in other works the didactic-pedagogical approach is much more theoretical. Pedro de Alcalá also states that his grammar is more a practical introduction, not a learned theoretical work. His approach reveals itself to be universalist, since he observes that there are definitions and explanations in one language in respect to the expression of its concepts in its own terms, these are the same in all other languages regarding the expression of their own concepts. Thus for the same reason that this name 'Pedro' is a proper noun in Latin, it is also such in 'Arabic' (Alcalá 1505[1883], 2). This observation is characteristic of Renaissance grammars in general and can be found in many other sources from this period. As Vivian Law observed:

Questions as 'what is a proper noun?', 'what is a verb?' 'how many word classes are there?' 'what are properties of the conjunction?' are as close to universal as any you are likely to find in a medieval grammar. Such concerns apply equally well to any European language; indeed, they had already been transferred from Greek to Latin. There is no inherent reason why they should not also be asked about Old Irish or Old Icelandic: one can find proper nouns (for instance) just as easily there as in Latin. (Law 2002, 191)

Obviously, Alcalá did not find it necessary to give his pupils definitions of the parts of speech, since they are the same for all languages. So one would wonder why the author decided to include Arabic grammatical terminology, which seems to be in contradiction with his own 'universalistic' approach. A possible explanation is that he did this only for 'scientific' reasons. He might have introduced them with the purpose to have a more adequate or sophisticated framework to fit in phenomena

letra castellana: tomando primero el arauia, ligeramente pueden venir en conocimiento del aljamia)." (Pedro de Alcalá 1505, prologue, ii v.) See also Cowan (1981, 358). [As the 'aljamiados', or old Christians can learn Arabic through this work, coming from Romance to Arabic, so the Arabs (or new Christians), having mastery of the Castilian alphabeth, taking first the Arabic, easily can have knowledge of the 'aljamia'].

${ }_{8}$ His purpose was "hazer vocabulista de la habla comun y usada de la gente deste." (ibid.) "to compose a dictionary of the common speech and used by the people." 
he was not so familiar with. As has been demonstrated by Cowen, this is only in a few cases a satisfactory explanation. Sometimes Arabic terms are only used as equivalents or translations of Latin terms. Clear examples are the names for the cases in the nominal paradigm. Pedro de Alcalá recognizes when dealing with 'declensions' that the Arabic noun has only one declension, since all Arabic nouns are invariable. ${ }^{9}$ However, admitting that there is only one declension, he states that Arabic nouns have six cases. We reproduce here the table according to Cowan (1981, 359):

TABLE 1 THE SIX CASES ACCORDING TO PEDRO DE ALCALÁ

\begin{tabular}{|c|c|c|}
\hline Alcalá & Translation & Classical term \\
\hline $\begin{array}{l}\text { mubtedĕ } \\
\text { 'subject' }\end{array}$ & 'nominatiuo' & mubtada' \\
\hline $\begin{array}{l}\text { mudăf } \\
\text { 'genitive' }\end{array}$ & 'genitiuo' & mudāf \\
\hline $\begin{array}{l}\text { maxrŏr } \\
\text { 'dative' }\end{array}$ & 'datiuo' & majrūr \\
\hline $\begin{array}{l}\text { mafu' } \breve{u} l^{10} \\
\text { 'object' }\end{array}$ & 'acusatiuo' & $m a f^{\prime} \bar{u} l$ \\
\hline $\begin{array}{l}\text { munĕde } \\
\text { 'vocative' }\end{array}$ & 'vocatiuo' & munādā \\
\hline $\begin{array}{l}z \text { arf } \\
\text { 'adverb' }\end{array}$ & 'ablatiuo' & zarf \\
\hline
\end{tabular}

As William Cowan observed:

they are not true cases in either the Arabic or the Latin sense of being an inflection added to a noun, a fact that Alcalá was quite aware of, but are regarded by him in the same way that modern theoreticians of case grammar regard the syntactic positions in an utterance. Such relations are not expressed by inflections, since colloquial Arabic has none, but through abitudines or conocimientos. The markers of the equivalents of these Latin cases are in fact combinations of prepositions and particles and the definite article (lil, maal, lal, etc.) (Cowan 1981, 359).

9 "La declinacion de todos los nombres arauigos es vna solamente. Porque todos los nombres arauigos son inuariables” (Alcalá 1505, capitulo nono).

${ }^{10}$ In the original text, a small hamza in superscript is placed on the first vowel ' $u$ '. 
The information given by William Cowan, however, is not complete, since translations from his dictionary are not included here. Although we do not find all the terms in his dictionary, we do find some of them: mubtedĕ is not only translated by Pedro de Alcalá as 'nominative', but also as 'principio de oracion' (Corriente 1988, 12), which is not without importance (see below). Ízm mudáf is rendered as "posesivo nonbre."

The term 'abitud' seems to be inherited from other grammars than the Latin and Castilian grammars of Antonio de Nebrija (c. 1444-1522). The term 'habitudo' is used by Ferdinandus Nepos in his Materies (completed between 1469 and 1485) and Juan de Pastrana Compendium grammatica (1462). ${ }^{12}$

Item per hanc regulam primo iuvenes component per unum casum tantum sic dicendo: la tierra 'terra'; de la tierra 'terre', etc.; uel per duos, sic: la tierra del rey; uel per tres et quatuor et amplius, sic: o leyente la lection a los scolares en el general de las escuelas componitur 'o legens lectionem scolaribus in generali scolarum', dando cuilibet casui propriam habitudinem, interrogando cuius casus, numeri et cuius declinationis hoc principio. (Codoñer 2000, 90).

However, it is not so clear what Pedro de Alcalás exactly means with the term 'abitud' (pl. 'abitudines'), since he uses it as a synonym of the definite article ('Nota que porque ay algunas abitudines en cada vno delos casos que en alguna manera parescen preposiciones, porque se preponen alos casos, avn que en verdad no lo sean, mas son articulos') (Alcalá 1505[1971], 26). In another section, Alcalá uses the term as a synonym of 'preposicion', since according to his observations, the maxrór case (see below) has the four 'abitudines' la, lal, li, lil, whereas the term 'abitud' is not used for $b a, b a l, b i, b i l, f a$, etc. which are described in the paragraph on the zarf case (Alcalá 1505[1971], 27). Here they are just called 'prepositions' and not 'abitudines' and there is no explanation

\footnotetext{
${ }^{11}$ Other terms not mentioned by Cowen, are 'jezme', translated as 'consonante' (letra mazjun [sic] (Corriente $(1988,34)$, and 'médde', translated as 'acento' (Corriente 1988, 189).

${ }_{12}$ "With this rule, the novices first build constituents with only one 'case' [= 'head' of the NP], saying "la tierra" 'terra', "de la tierra", 'terre', etc., or with two 'cases' [= 'head' + complement of the NP], as "la tierra del rey", or with four and so on, as: "reading the lesson in general for the scholars of the schools," assigning the appropriate "habitudo" [= grammatical form] to whatever case [= grammatical function]. The term 'habitudo casualis" is also used by Nepos in relation with government: "Haec enim regula maxima est in construendo [...] quia talem casum regit dictio qualis fuerit habitudo casualis." (ibid.).
} 
why he used these different terms. In other sections, Alcalá uses 'abitud' as synonym of 'conocimientos' (see also Zwartjes 1993, and 1994).

In Arabic grammatical theory a nominal sentence can be divided into 'topic' for which mubtada' (lit. 'what is begun with') is normally used, and 'comment' (xabar), or 'predicate' (Owens 1988, 32), or according to Sïbawayhi's terminology also called mabnìy 'alā-l-mubtada' ('what is built upon what is begun with') (Owens 1990, 45). Mudāf is the word Pedro de Alcalá uses for the genitive, which in Arabic tradition means literally 'what is added', i.e. possessed (Owens 1988, 34; 1990, 104). Majrür from the same root as jarr (see below), means 'pulling, or governing the $-i$ inflected form. Pedro de Alcalá follows in his sections about the prepositions the Latin system and tries to apply Arabic terms to them, without realizing that in the dialect he describes, case-endings are not used, and without realizing that in classical Arabic nominal declension, there are three inflectional vowels, the $-u$, the $-a$, whereas for the verbal inflection the three vowels $-u,-a$ and $ø$ (zero ending) can be distinguished. Pedro de Alcalá did not take the Arabic inflectional endings as starting point, but the Latin prepositions in alphabetic order: prepositions + accusative, prepositions + ablative, etc. and at the same time he translated the names of these 'Latin' terminology into Arabic:

\section{Capitulo XXXII. De las preposiciones.}

Hallamos en el Arauia todas las preposiciones que en la gramatica [latina], y ayuntadas a essos mesmos casos, que son mafúul y darf (que son acusatiuo $y$ ablatiuo), $y$ son las del acusativo las siguientes:

$$
\begin{array}{lllllll}
A & \text { ad apud circa circa ante longe ante } & {[\ldots]} \\
A & \text { al aynd carib qued acábal baád cudim } & {[\ldots]}
\end{array}
$$

Las preposiciones del darf (que es ablativo) son las siguientes, conuiene saber:

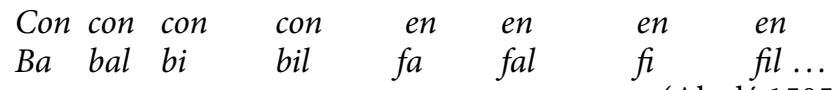

(Alcalá 1505[1883], 26).

"Chapter XXXII. About the prepositions.

We find in the Arabic language all the same prepositions as in Latin grammar, and they are combined with the same cases, which are maf' $\bar{u} l$ and $z \operatorname{arf}$ (which are accusative and ablative), and those which can be combined with the accusative are the following:
A. ad
apud circa
circa ante
longe
ante $[\ldots]$
$\mathrm{A}$ al aynd carib
qued acábal baád
cudim $[\ldots]$ 
The prepositions of the $\operatorname{darf}$ (which is ablative) are the following:

$\begin{array}{lllllll}\text { con con } & \text { con } & \text { con } & \text { en } & \text { en } & \text { en } & \text { en } \\ \text { ba bal } & \text { bi } & \text { bil } & \text { fa } & \text { fal } & \text { fi } & \text { fil ..." }\end{array}$

As we can see, Pedro de Alcalá did not separate the prepositions from the definite article $(a l)$.

$M a f^{\prime} \bar{u} l$ is the term used for 'object.' Sïbawayhi distinguishes five subtypes: maf 'ül bihi 'direct object', maf' ül fìhi 'locative object', maf 'ūl ma'ahu 'accompaniment object', maf ül lahu 'reason object', and maf'ül minhu 'object from it'. (Owens 1990, 160). For the 'locative object', instead of maf' $\bar{u} l$ fin $i$ the term $z a r f$ is also used (Owens 1990, 51,141-151), which is the term Alcalá uses here for the 'ablative'. Munādā is the direct translation of 'vocative'. According to Cowan $(1981,360)$, Alcalá 'was apparently trying to make unfamiliar material intelligible to his audience, but at the same time to avoid a direct equation with the Latin categories.' In fact, the first might be true, but we must be aware that in his paradigm of the case-system, we do find an equation with Latin cases, and we never find any traces of the four traditional Arabic inflectional endings, -zero, $-u,-a$, and $-i$ and never the original Arabic names for these inflectional endings are introduced here.

Other technical grammatical terms in Alcalăs grammar are: 'amir ('conocimiento'; ; ${ }^{13} \mathrm{cl}$. Ar. damīr 'conjunct pronoun'), temiz (cl. Ar. tamyīz 'accusative of specification'), ${ }^{14}$ amr ('imperatiuo'; cl. Ar. 'amr 'imperative'), xucla 'señal'; cl. Ar. šakl(a) 'orthographic sign': ${ }^{15}$

Es otrosi de notar, que los Arauigos non tienen letras vocales como los Latinos, mas tienen en lugar dellas ciertas señales, que ellos dizen xúclas, con las quales y con todos los caracteres suso dichos leen y escriuen lo necessario (Alcalá 1505[1883], 4).

It has to be observed that the Arabs do not have the letters for the vowels as the Latins, but instead of them, they have certain signs, which they call xuclas, and with all the above-mentioned characters they read and write anything which is necessary.

\footnotetext{
13 Cf. Zwartjes (1994).

${ }^{14}$ Temı̌ç is also translated as 'conocimiento' in his dictionary (Corriente 1988, 197).

${ }^{15}$ In his dictionary Alcalá translates the word â̂léma as '(signo por) señal' (Corriente 1988,140 ). The señal is also used in his grammar for the article (señal de demostración), so this term could be the technical grammatical term, but as happens often in these grammars, it is not always possible to distinguish between language and metalanguage.
} 
The origins of the mnemonic vowel terms with and without tanwin (the 'nunated' forms) which expresses indefiniteness in Arabic are unknown to me and this could be a local teaching method, not recorded elsewhere:

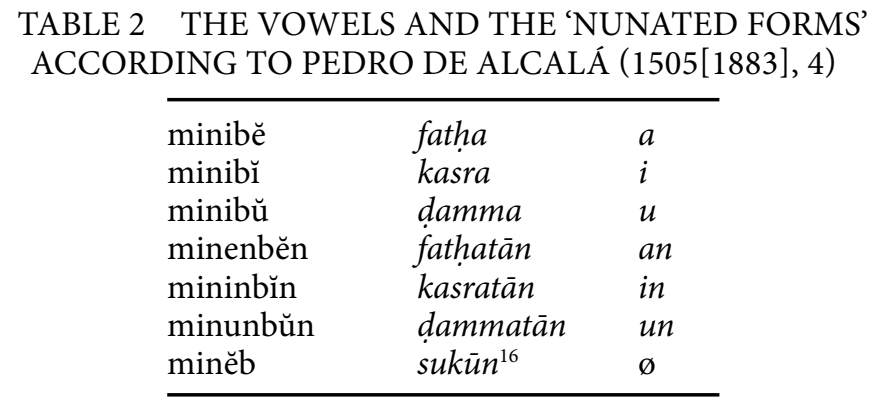

The remaining Arabic terms analyzed by Cowan are alifcequin ('alif sākin 'silent 'alif'), and in his dictionary we find iarab ('oración de gramática'; clas. Ar. ' $i$ 'rāb (the inflectional endings $\varnothing, a, i, u$ (see below) ${ }^{17}$ and harf ('letra'; Cl. Ar. harf), which are not analyzed at all in the grammatical treatise.

Summarizing the preceding paragraphs, we can conclude that in most cases Pedro de Alcalá could easily use Latin terminology, such as the names for the cases or the imperative. The use of an 'exo-grammatical' term damir for the conjunct pronoun does make sense since traditional grammar did not have precise equivalents from contemporary sources yet. Probably, Pedro de Alcalá understood very well that the conjunct pronoun in Arabic can be used differently from the Spanish pronouns; they can also be affixed to prepositions and nouns, for instance and that explains probably the reason why he used the Arabic term. In the remaining cases, Arabic terms are used for mnemonic or pedagogicaldidactical reasons. It is questionable if these terms made his teaching

${ }^{16}$ The terms fatha, kasra and damma are not found in his grammar which gives us the impression that Pedro de Alcalá did not know them.

${ }^{17}$ Again, we find more information in the dictionary, neglected by Cowan: iaráb is translated as 'declinacion de palabras' (Corriente 1988, 134), which is not unimportant because the author avoids the term 'noun' here, since 'i $i a \bar{b} b$ is used for nouns and verbs as well. 
method more attractive or more easily accessible to his pupils. ${ }^{18}$ Seen through our modern eyes, the grammar of Pedro de Alcalá was a real novelty, a pioneer work. His transcription system of the Arabic alphabet is the first in Europe, although his knowledge of classical Arabic was evidently limited; there are quite a few inconsistencies while using his own transliteration system. It is also obvious that Pedro de Alcalá did not have any knowledge of Arabic grammatical theory and his Greco-Latin approach is particularly visible in the lacking of insights in the analysis of derivations. As had been observed by Fück [Pedro de Alcalá] "erkennt nicht die Bedeutung des Wurzelbegriffs, so dass dem Leser der arabische Formenbau in der Nominal- wie in der Verbalbildung undurchsichtig bleibt" $(1955,33)$. Nevertheless, as has been stressed by several scholars at the conferences on missionary linguistics, ${ }^{19}$ it is easy to point at the shortcomings of these grammars and dictionaries measured by the standards of our own time, but when studied and analyzed in its own historical and cultural context, there is no doubt that there is still a wealth of material to be studied. As observed by Smith Stark "certain preconceptions about pre-modern descriptive work have resulted in its neglect among those in the Western tradition" $(2005,4)$. Monographs and studies on the description of Arabic by Spanish missionaries are still non-existent. Positive evaluations are scarce when the grammars are concerned, whereas the majority agrees that the lexicographical work of Pedro de Alcalá and others have been of great value. Dannenfeldt's observation, according to whom "Both of these [Alcalăs] works are based on solid

\footnotetext{
${ }^{18}$ Missionaries usually emphasised that the language they were learning was 'easy' to learn, although others label the language under description as 'difficult.' They tried to use the most transparent and less 'obscure' paradigms and explanations. The reason to re-write existing grammars was almost always because predecessors were too 'obscure'. Probably, the grammar of Pedro de Alcalá could be perfectly understandable without the use of Arabic grammatical terminology. The same could be said of the use of Hebrew posodical-grammatical terms by Oyanguren de Santa Inés in his grammar of Tagalog (1742, 208-209), such as milehal (stress on the penultimate syllable, instead of the usual ultimate syllable, in connection with stress assignment), athnach (semicolon or pause) and metheg (one type of the several secondary accents, avoiding the loss of vowels in pronunciation, or a sign, pointing a vowel, which usually would be reduced to schwa but which is to be fully pronounced in this particular place). The terms 'atnach and meteg are both so-called 'cantillation marks' in the Hebrew Bible from Masoretic times. Did the pupils of Oyanguren de Santa Inés know Hebrew, or is this pure pedantry or snobbism?

${ }^{19}$ The International Conference on Missionary Linguistics took place in Oslo (2003), São Paulo (2004), Hong Kong and Macau (2005), Valladolid (2006), Mérida (Yucatán, 2007) and the sixth will be organized in Évora, Portugal.
} 
philological methods and are evidences of humanist learning in Spain" $(1955,33)$,-when compared to Fück's $(1955,33)$-is without any doubt an exception. Although Pedro de Alcalâs grammar served as the model for the Gramática arábigo-castellana (still unpublished) composed by the Hiernoymite Patricio José de la Torre (1760-1819) ${ }^{20}$ and although we have some evidence the Maronite Joseph Simon Assemani of Syrian origin (1687-1768 $)^{21}$ quoted from his grammar, Alcalás dictionary was particularly widely known and used throughout Europe. Johannes Gabriel Sparvenfeldius possessed probably Alcalás catechism, which has been appended to his grammar and his dictionary already in 1706 but in that period it had become already a rare book (Schnurrer 1811, 16). ${ }^{22}$ If the original work was not longer available, scholars used the original editions or the re-edition from 1776 from Patricio José de la Torre with transcriptions into Arabic characters, which was the base for the Supplément of the Dutch Orientalist Reinhart Dozy (1820-1883) (Monroe 1970, 38). One of the main purposes was to publish the work of Pedro de Alcalá in Arabic script, something that was completely unnecessary according to Pedro de Alcalá. Although we find an entire page with the Arabic alphabet in his grammar, an observation below it tells us "all characters can be substituted by Latin or 'Castilian' letters":

Estos son los caracteres y nonbres de las letras arauigas, las quales todas se pueden suplir con nuestras letras Latinas o castellanas, de manera, que para la comun algarauia no ay necessidad de las saber ni conocer todas, mas solamente quarto conuiene saber kha, dil, te, ay, cuyos sones no tenemos en nuestro ABC latino. (Alcalá 1505[1883], 3-4)

These are the characters and names of the Arabic letters, which all can be substituted by our Latin or Castilian letters, so that there is no need to learn or to know them all for the common speech, but only four [are necessary], namely the kha, dil , te, ay, whose sounds we do not have in our Latin ABC.

We have seen that for didactic reasons, Pedro de Alcalá used these mnemonic words, which are not derived from canonical grammatical works of the Arabic tradition. Other grammarians found a different

\footnotetext{
${ }^{20}$ Schnurrer (1811, 88, no. 128). BICRES III, no. 84.

${ }^{21}$ Schnurrer $(1811,16)$ observes that Assemani quotes from his grammar 'ex grammatical recitat,' but also adds that he actually used material from Alcalás dictionary ('non Grammaticae sunt, sed Vocabularii,' ibid.).

${ }_{22}$ Ioan. Gabr. Sparvenfeld. 1706. Catalogus Centuriae Librorum Rarissimorum Manuscript.\& partim Impressorum, Arabicorum, Persicorum, Turcicorum, Graecorum, Latinorum, \&c. Upsala: John Henry Werner.
} 
solution. One of the most remarkable solutions can be found in the Fabrica Arabica (1640) of Dominicus Germanus of Silesia (1588-1670). In this case, we have translations of the Latin names of the cases into Arabic. In the following table we see these literal:

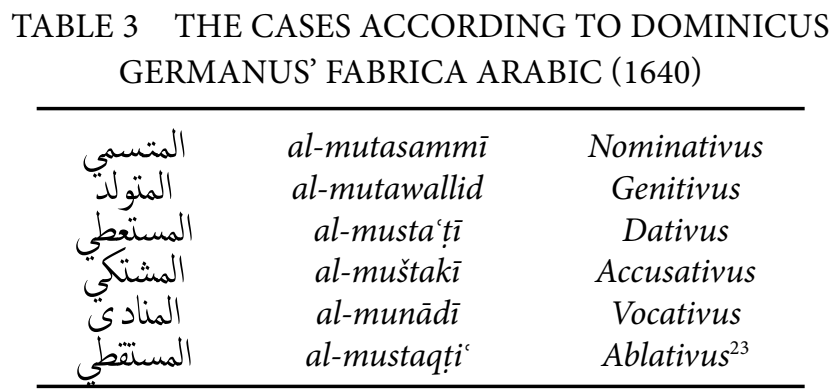

3. The grammars of Lucas Caballero, Juan de la Encarnación, and Francisco Cañes: 'Grammars at the crossroads of two systems?'

\subsection{Introduction}

After the foundation of a great number of missions in the East, the importance of the Arabic language for preaching the Christian faith continued to increase. Paul V in a papal bull dated 1610 had commanded the various religious orders to teach Oriental languages in their colleges. In the early 16th century, Arabic was taught in Seville at the Colegio trilingüe. ${ }^{24}$ The Franciscans decided to found colleges in Salamanca, Alcalá, Paris and Toulouse for the teaching of Arabic, Greek and Hebrew (Monroe 1970, 26). According to Monroe, Bernardino González (c. 1665-1735) composed an Arabic dictionary in Seville, which was completed by Franciscans in Jerusalem in 1709 (Monroe ibid.), an unpublished work. José de León began to compile a new dictionary of Arabic and Bernardino González was sent to Damascus in order to complete his work. ${ }^{25}$ As Monroe

\footnotetext{
${ }^{23}$ From the verbs sammā 'to denominate,' walada 'to give birth,' 'a'tāa 'to give', šaka 'to complain,' nada 'to call' and qatta 'to cut off, to disjoin,' the tenth derived form means 'to deduct', which seems to be an approximate translation of 'auferre.

${ }^{24}$ In this short account, there will be no space to summarize the study of languages during the Middle Ages in Muslim Spain.

${ }^{25}$ Franciscans had already arrived in 1233 in Damascus. Propagating the Christian faith was not permitted by Sultan Malik al-Ašraf, but they took care of Europeans who settled there. After several cases of martyrdom and imprisonment, the Cadi of the city
} 
observed, 'the work was the most complete ever to have been composed in Spanish after that of Pedro de Alcalá. [...] The work of González and his collaborators was lost until Asín Palacios (1901) came across a copy containing additions up to the year 1727 made by the friars of Damascus' (Monroe 1970, 27). One of the successors of Bernardino González was Francisco Cañes who settled in Damascus at the Spanish Franciscan College in 1757 (Monroe 1970, 28). Cañes' grammar of Arabic has been printed in two different editions, a first in 1775 (Madrid, Don Antonio Perez de Soto, and a second in 1776 (Schnurrer 1811, no. 113, BICRES 959 and 971), entitled Gramatica arabigo-española, vulgar y literal. Con un diccionario arábigo-español, en que se ponen las voces mas usuales para una conversación familiar, con el texto de la Doctrina Cristiana en el idioma arabigo.

I came across another copy from the same Franciscan tradition, composed by Lucas Caballero and Juan de la Encarnación as we can read in the colophon, which escaped the attention of scholars who have worked in this field. The manuscript has been identified by Magnus and Aare Mörner in his Spanien i svenska arkiv. The title of this manuscript is Compendio de los rudimentos y gramática árabe en que se da notizia de la lengua vernácula y Vulgar y algunas reglas de la literal Iustamente, 1709, and in the colophon 1710 (another author, Juan de la Encarnación, finished the text San Diego, Seville). The work is based on Bernardino González as we can read in the title, and Lucas Caballero, "lector actual Arabo en el Colegio de Damasco" composed ('recopilado') this manuscript, which has been donated by Johan Adam Tingstadius (1748-1827) ${ }^{26}$ bishop of Strängnäs, Sweden, from 1803, to the Rogge library, which has belonged administratively to the Royal Library of Stockholm since 1968.

As the titles of the grammars of Cañes and Caballero demonstrate, the language under description is not only classical Arabic, but the urban dialect of Damascus. Apart from Alcalás grammar of colloquial Arabic of Granada, European scholars usually did not pay much attention to lower registers, so the linguistic works of these Franciscans work-

granted the privilege of being able to open a public chapel and in 1668 the Franciscans established themselves in a Maronite church, which they left in 1719 when they acquired a new church in the Christian Quarter of Bāb Tüma. The foundation of the college where Arabic was taught dates from this period.

${ }_{26}$ Tingstadius was a professor in Oriental languages at Uppsala. He published, for instance in 1770, a treatise entitled Dissertatio philologica de natura et indole linguarum orientalium communi (Uppsala: Johan Edman) and in 1794 his Dictiones arabicae ex carmine Tograi, hebraismum biblicum illustrantes. Uppsala: Johan Edman. 
ing in Damascus are of great importance. However, they were not the only grammarians who described non-Classical registers. Antonio ab Aquila's grammar published in 1650 is not only a grammar of classical Arabic ("ad grammaticae doctrinalis intelligentiam") but also colloquial Arabic ("ad vulgaris dumtaxat idiomatic"), probably the reason why he called the grammar "Arabicae linguae novae et methodicae institutiones." Dominicus Germanus (Germanus of Silesia; $1588-1670)^{27}$ composed a dictionary in 1636 with the title Fabrica overo Dittionario della lingua volgare arabica et italiana, copioso di voci e locutioni, con osservare la frase dell'una e dell'altra lingua (Roma. Nella stampa della Sac. Congr. De Propag. Fide) followed three years later by his Fabrica linguae Arabicae cum interpretatione latina et italica, accommodata ad usum linguae uulgaris et scripturalis (Roma. Typis Sac. Congreg. De Prop. Fid.).

In 1800 a work has been completed by Franciscus de Dombay (17581810) with the title Grammatica linguae Mauro-Arabicae juxta vernaculi idiomatis usum, accessit vocabularium Latino-Arabicum (Vindobonae: apud Camesina ${ }^{28}$ but, according to Schnurrer, this title is misleading; although this grammar describes the common speech of the people in the Maghreb ("Arabicus sermo in Mauritania quo vulgus uti solet"), he observes that all words are 'good Arabic' ("non sunt vulgari idiomati propria, sed omnia bene Arabica”) (Schnurrer 1811, 95). ${ }^{29}$

\footnotetext{
${ }^{27}$ Germanicus was a teacher of Arabic at the mission school St. Peter in Montorio, Rome. He assisted with the preparation of the Arab Bible, he published dictionaries, and commentaries on the Qur'ān. He was teacher and translator at the court of Philip IV of Spain.

${ }^{28}$ I have not been able to consult this grammar yet.

${ }^{29}$ Although this is not the aim of this paper, I wish to show just a few elements from these sources that are important records of colloquial Damascene Arabic from the beginning of 1700. Particularly the word lists are full of colloquialisms, but also the grammar of Lucas Caballero has many colloquial elements, to mention a few: omission of vowels: muqatla instead of muqätala, the use of the $-u$-vowel as a prefix for the imperfect tense (64), $b$ - future suffix (p. 24), which is colloquial (in Egypt it is the present tense). However, Caballero is not always consistent, we find both fa'altu as fa'altum (2 person pl.m.), the use of $-\bar{\imath}$ instead of -ina for the second person feminine singular in taf'ali (= 'Haztu fem.) (72). It is remarkable that sometimes we find even hybrid forms, such as antum fa'altu. However, we find also classical elements, such as the use of the feminine plural in the verbal paradigms, which is not used in colloquial urban speech today. It is also significant that the order of the persons singular in the verbal paradigms is not the traditional one 73v-72r. Cañes has 3 (masc. Sing, 3 fem. Sing, 3. plur. 2 masc. Sing. 2 fem. Sing. 2 plur. 1 sing 1 plur. Instead of 3,3,2,2,1 (sing.), 3, 3, 2, 2, 1. I am grateful to Manfred Woidich for his comments on this footnote.
} 
Grammars of Classical Greek were available throughout Europe, but Spanish priests were engaged in the writing of vernacular Greek too, as we can read in the prologue of Francisco Cañes $\left(1775\right.$, s.n.). ${ }^{30}$

In the following paragraphs we will treat the use of Arabic terminology in both grammars separately.

\subsection{Semantic and inflectional vowels and the concept of 'amal}

The questions to be answered now are: which Arabic grammatical terms are used, particularly in the sections dedicated to inflection and government, what did they mean and why did Caballero and Cañes use them?

Let's start with the vowel system, according to the paradigm of Caballero are:

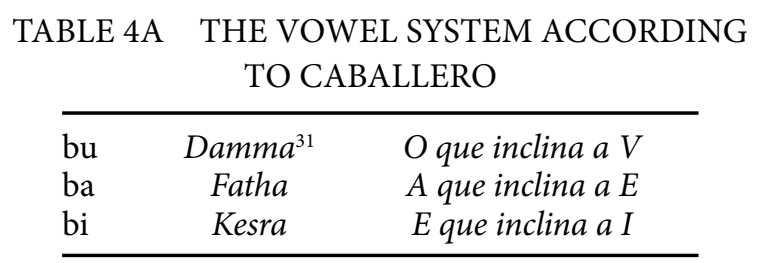

Unlike Pedro de Alcalá, Caballero gives also in an appendix of this Chapter the Arabic technical terms for these vowels when they are used as inflectional endings, accompanied with translations into Spanish:

Los Gramaticos a estas mociones dan otros nonbres conbiene a saber que significan, eleuacion, ereccion, y contraccion: al-raf, al-nasb, wa-l-jarr y estas mociones duplicadas llaman tanuin (tanwin) esto es nunacion que es

${ }^{30}$ It must be emphasized that missionary sources, often written in Spanish, are in many cases the only existent sources which can give us information of vernaculars once spoken in early ages of languages of which we only have more detailed information concerning the literary or classical register. Priests understood very well that in China the teaching of Mandarin was not so useful in regions were other dialects were spoken.

Grammars of modern Greek circulated since 1638, the Grammatica linguce grcecoe vulgaris was printed by Simon Portius. The first Spanish grammar of modern Greek was composed by Pedro Fuentes, as we can read in the following quotation from the same prologue: "Por lo tocante á la lengua griega ha impreso su gramatica vulgar Fr. Pedro Fuentes observante, que residió en el Seminario de Nicosía en Chipre, y ahora está imprimiendo la gramatica literal."

${ }_{31}$ In their tables of the vowel system, both authors also give the names of the vowels in Arabic script, not reproduced here. 
lo mismo que decir addicion de un sonido de nun o n y biene a sonar on, an, en vg. Racholon, Racholan, Racholen, Homo, Hominem, Hominis [...] pero esto ueras mas claro en el tratado del nonbre (77 r.).

The grammarians give other names to these 'motions' [harakāt], namely the names which signify 'elevation', 'raising', and 'contraction', ar-raf', $a n$-naşb, wa-l-jarr, and these 'motions', when duplicated, are called tanwìn, which is 'nunation' which is the same as adding the sound of a $n \bar{u} n$, or $-n$, which approximately sounds as on, an, en vg. Racholon, Racholan, Racholen, Man (nom.), man, (acc.), man (gen.), but this you will see more clearly in the chapter about the noun."

Cañes' table resembles that of Caballero, although there are some differences. The order of the vowels is different, Spanish translations of the Arabic vowel terms are given, and instead of de verb 'inclinar' we find 'declinar':

\section{TABLE 4B THE 'INFLECTIONAL' VOWELS ACCORDING TO CAÑES} $(1775$, f. 7$)$

\begin{tabular}{lcl}
\hline ba & Fatha, Apercion & A que declina á e, y a clara. Ba, ó Be. \\
bi & Kesra, Fraccion & E que declina en e, ó i claro. \\
bu & Domma, Colleccion & O que declina en o, y u. como Bo, ó Bu. \\
\hline
\end{tabular}

Also here, we find almost the same observation as above, which demonstrates that the works are closely related to each other and that they probably derived from a common source (or sources):

Los gramaticos à las tres mociones dichas les dan otros nombres, es á saber: al Fatha le llaman 'Nasbo', esto es 'ereccion', al 'Kesra Charro', 'contraccion', y al 'Domma Rafo', 'elevacion'. Suelen tambien duplicar las dichas mociones de esta suerte $(")\left({ }^{(*}\right)$, y entonces les dan el nombre 'tanuin', esto es, 'nunacion', ò 'nun' vocal, que viene á sonar 'an', 'en', 'on'. (Cañes 1775, ff. 8-9).

The grammarians give other names to these three above-mentioned 'motions', namely: they call the Fatha 'Nasbo' which means 'erection', they call Kesra 'Charro' which means 'contraction', and Domma Rafo 'elevation'. They are used to dublicate the above-mentioned 'motions' in this way: (") $\left({ }^{v}\right)$, and they give them the name tanwin which is 'nunation', or vocal nün which sounds rougly like: an, en, on.

In Chapter 4, both authors deal with the 'cinco signos':

(1) Secun ('quietud'), which has according to both the synonym chezm ('caballero'), or chiasmo (Cañes), (jazm) which Caballero translates as 'anputacion' and Cañes as 'corte';

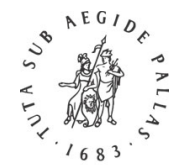


(2) Texdid ('duplicacion, ó corroboracion');

(3) Maddo ('extension ó produccion');

(4) Vasalo ('union, ò conjuncion'); and

(5) Hamza ('punzamiento').

A chapter dealing with how to read Arabic without vowel signs was appended by Caballero, not present in the grammar of Cañes. Although there are differences, both grammars are from the same tradition and both authors (re-)formulated probably the lost version of Bernardino González, or quoted directly from other sources, such as Agapito à Valle Flemmarum, who almost has the same definitions as Cañes's, although the vocalizations of the Arabic terms and the order is slightly different:

\section{TABLE 4C THE 'INFLECTIONAL' VOWELS ACCORDING TO}

$$
\text { AGAPITO À VALLE (1687, f. 79V.) }{ }^{32}
$$

\begin{tabular}{lll}
\hline bu Dzhamma, collectio & o declinans ad u, \& u claru” \\
ba Fathha, aperitio & a declinans ad e, \& a claru” \\
bi Kesra, fractio & e declinans ad $i$, \& i claru” \\
\hline
\end{tabular}

The 'Tratado III' deals with the noun. Here we find sometimes some parallels with the grammar of Pedro de Alcalá, particularly since the term 'señal' has been used in both sources, or 'notificación' for the article $^{33}$ and the 'abitudines' of Pedro de Alcalá resemble much the 'señales del nombre'. Since colloquial Arabic nouns are not inflected according to cases, we find in the grammars of Alcalá, Caballero and Cañes equivalents of the Greco-Latin cases for didactic reasons:

Los arabes aunque en la lengua vulgar reconocen tres numeros en el nombre, es saber: 'singular', 'dual', y 'plural' no conocen distinction de casos. Y asi el nombre en qualquier caso termina con una misma voz. (Cañes 1775, 59).

The Arabs, although they recognize in the colloquial speech three numbers in the noun, being, singular, dual and plural, they do not know the distinction in cases. And that's why the noun ends with the same sound in whichever case.

${ }^{32}$ The vocalization of Martelottus is slightly different: Dzhammon, Phathhon and Kafron.

33 Pedro de Alcalá uses 'señal de demostración'. See Zwartjes (1992). 
Elsewhere in his grammar, i.e. after the 'Numeros cardinales' and 'Numeros ordinales' we find a comparable description:

Los Arabos en la lengua Vernacular o Vulgar no tienen terminacion de casos en el nombre assi como los Castellanos (16v.).

In the vernacular or vulgar speech, the Arabs do not have the ending of cases in the noun as the Castilians have.

The case system according to Caballero is as follows:

TABLE 5 THE INFLECTIONAL VOWELS ACCORDING TO CABALLERO $(1709,14 \mathrm{r}$.)

\begin{tabular}{lccl}
\hline Nominativo Vocatiuo & $\begin{array}{c}\text { raf } \\
\text { un }\end{array}$ & Rajulun & Vir, o vir \\
Acusativo Vocatiuo & $n a s b^{\text {un }}$ & Rajulan & Virum o Virum \\
Genitiuo & $j a r r^{\text {un }}$ & Rajulin & Viri \\
Datiuo & & A viro \\
Ablatiuo & & & Airo \\
\hline
\end{tabular}

What did these terms mean in the Arabic grammatical tradition? Before Sibawayhi, no distinctions have been made between the vowels which are used in classical Arabic for the declensional endings, and the other vowels, for instance: there was no disctinction between both vowels ' $i$ ' in the 'genitive' al-kitâb-i. An important novelty of Sïbawayhi is that he distinguished the first ' $i$ ' that is non-declensional, from the final ' $i$ ' which is 'declensional' (Versteegh 1997, 19).

When we analyze Arabic terminology in our 18th century grammars, the sections about the particles are even more interesting. Cañes and Caballero use both a metalanguage inherited from the Arabic tradition that had already been developed by Sibawayhi:

These endings follow eight courses: accusative (nașb), genitive (jarr), nominative $(r a f)$, apocopate (jazm), a-vowel (fath), i-vowel (kasr), u-vowel (damm), zero-vowel (waqf). (Translation by Versteegh 1997, 36).

The main distinction is whether a certain vowel is declensional or not. The Arabic terms used by Caballero have all to be related to the Arabic term 'amal that generally is translated as 'governance', or 'dependence/ dependency', which resembles the 20th century theory of 'government and binding. As explained by Owens: 
The governor is said to govern the governed in some case or mode form ('i $i^{\prime} r \bar{b} b$ ):

For the nouns these forms are: $u$ nominative ( $\left.r a f^{c}\right) ; a$ accusative (nașb); $i$ genitive (jarr);

For the verb only the imperfect verb shows mode inflection: $u$ indicative $\left(r a f^{\prime}\right)$; a subjunctive (naṣb); Ø jussive (jazm).(Owens 1988, 39).

Carter demonstrated in several publications $(1991,1993,1994)$-dealing with different grammatical theories-that the translation of technical terms are in many cases inexact, problematic, anachronistic and can lead to misconceptions. ${ }^{34}$ Carter argued that the basic meaning of the concept of 'amal is different, stressing that the interpretation of Weiß: "amal und regere: 'Es ist nicht recht verständlich', wie man hier schwanken kann. 'amala fì kann ja doch gar nicht heißen 'Gouverneur sein über. [...]'. 'amala fì ist 'tätig sein, arbeiten.' The translation 'governor' is according to Weiß an example of wishful thinking ('Wunsch der Vater des Gedankes'), because the concept of governance was already widely used in the Greco-Latin framework. A translation that brings us closer to the original meaning "an etwas arbeiten, auf etwas einwirken" (Weiß 1910, 384).

Particles (hurūff) $)^{35}$ can also be defined as 'governors', since they can 'govern' cases. The subclasses of some particles can be defined in terms of 'dependency', i.e. which nominal or verbal ending they 'govern'. If a particle (harf) 'governs' a genitive, such particles are called hurüf jarr (Owens 1988, 10), for instance bi ('by means of'), or min ('from') etc. In both the Compendio delos Rudimentos y Gramatica Araba of Lucas Cauallero, as the Gramatica arabigoespañola, vulgar, $y$ literal of Francisco Cañes we find hispanicised forms of these subclasses of particles. ${ }^{36}$ At the beginning of the chapter dealing with the parts of speech, both Caballero and Cañes give us the tripartite division of the parts of speech, which is an 'Arabic' division, according to Cañes ('Pero los arabes las

${ }^{34}$ The same happened when Romans translated Greek grammar. An illustrative example is the term casus accusativus which is a wrong translation of the Greek term ptosis aitiatike. It is not the "anklagender Fall," but "das von der Handlung Betroffene, dasjenige, dem etwas gechieht." (L. Lersch: Die Sprachphilosophie der Alten, Bonn 18381841. vol. 2, 186, quoted in Carter 1993, 131).

${ }^{35}$ Harf does not only mean 'particle,' since it has in fact much more meanings, such as 'edge, letter, sound, word.' See for a detailed overview of the most important meanings the first Appendix of Owens (1990, 245-248).

${ }^{36}$ We have not been able to consult a dictionary, which is particularly devoted to the particles, the Diccionario de partículas árabes [s.a.], composed by Mariano Rizzi y Franceschi (18th century; BICRES III, no. 71). 
[partes de la oracion] reducen a tres, que son: verbo, nombre, y particula (harf).' As a matter of fact, the authors follow this tripartite division, but in the second chapter of the 4 th treatise, which deals with the particles, the author prefers to follow the Latin model:

Capitulo II. De las particulas separadas.

Muchos son los generos, que hay de estas particulas, y para evitar confusion, las dividiremos al modo de los latinos, en 'adverbios', 'conjunciones', 'preposiciones', $y$ 'interjeciones'. (71).

"Chapter II. About the separate [= not suffixed] articles.

The subcategories of these particles are many, and in order to avoid confusion, we divide them, according to the Latin manner, into adverbs, conjunctions, prepositions and interjections."

In the pages dealing with classical Arabic, a separate chapter following the final chapter in syntax, Francisco Cañes again prefers the Arabic model. In the following quotation he deals with them after the chapter on syntax describing classical Arabic:

Aqui es preciso advertir, que asi como el nombre se declina por la variacion de las terminaciones, que tiene en los casos, como adelante se verá; igualmente el verbo en el 'modsareo' se conjuga de tres maneras: por variarse su terminacion en las personas. Esta variacion proviene, de que los arabes anteponen al verbo en el 'modsareo' dos generos de particulas, que se llaman 'nasbantes' y 'chazmantes'. Se llaman 'nasbantes' del verbo 'nașaba' puso, plantó, fixó, porque en fuerza de ellas el 'domma' de la tercera radical del verbo se pierde, y convertido en la mocion 'fatha', la fixan, y plantan sobre la dicha radical, sin que padezca mutacion. Las 'chazmantes' se llaman asi del verbo 'jazama' secó, ${ }^{37}$ cortó, porque estas particulas le cortan la mocion á la tercera radical; y poniendole el signo 'secun', la dexan quiescente, ó liquida. (Cañes 1775, 109-110).

Here, it is necessary to observe, that as the noun declines through the variation of its endings which they have in the cases, as we shall see below, so on the same manner the verb in the mudāri $i^{i 38}$ conjugates in three ways: by varying the endings according to persons. This variation results from the fact that the Arabs put before the verb in the mudāri two classes of parti-

${ }^{37}$ Probably 'seccionó', since 'secar' means 'to dry.'

38 Usually translated as "imperfect," literally 'the resembling verb' (Baalbaki 2004, XIII, 23), because they resemble the nouns, since both share the same declensional vowels ('i $i r \bar{a} b)-u$ ('subject' and 'indicative mood'; and $-a$ which is 'direct object' and 'subjunctive mood'). The nouns do not have zero endings ('apocopate' or jussive mood in the verbal system), whereas the nouns have the $-i$ ending ('genitive'), which is not present in the verbal paradigm. 
cles, which they call 'nasbantes' and 'chazmantes' [= which co-occur with the nassb ( $a$ ending) and those which co-occur with the jazm ( $\varnothing$ ending)]. They are called nasbantes from the verb nașaba, to put up, to plant, to fix, because through their force, the domma [damma] of the third radical of the verb is cut off and converted into the fatha [ $a$ ending/'motion']; they fix this radical and settles down on it, while it does not suffer any change. The chasmantes [those which co-occur with the zero-ending] are called so from the verb jazama, to cut off, to truncate, because these particles cut off the vowel ['motion'] from the third radical, and put on this the sign sukūn ['motionless', 'vowelless'] and leave them 'silent' or 'liquid'.

In Chapter IV, dealing with the noun, Cañes gives us three classes of particles, 'charrantes, chazmantes y nasbantes':

Particulas 'charrantes' son unas preposiciones, que antepuestas al nombre le colocan en el caso 'charro', ó 'genitivo' (139) [...] Aqui se debe advertir, como en arabe lo mismo es de decir particula 'nasbante', que en latin preposicion de acusativo, y asi antecediendo al nombre le colocan en dicho caso, [...] Estas particulas á manera de los verbos, admiten afixôs, y rigen los nombres, colocando el sujeto en 'nasbo', ó 'acusativo', y el predicado en 'rafeo', ó 'nominativo', de suerte, que se viene hacer una permutacion del nominativo con el acusativo... (143)

the particles which are 'charrantes' are some prepositions, which placed before the noun, put it in the jarr [i] ending, or genitive. Here it must be observed, that as in Arabic it is the same to call them 'particular nasbante', as in Latin, prepositions which combine with the accusative, and as such they are placed before the noun, they put it in this so-called case. [...] These particles, when combined with verbs, allow affixes, and govern the nouns, placing the subject in nașb, or accusative and the predicate in raf', or nominative, so that there is a permutation from the nominative to the accusative.

Caballero uses the same classification and terminology, although his hispanicised forms are slightly different: 'particulas charrantes, nassuantes', and 'chesmantes'. Although in Cañes' description, only classical Arabic is commented on, Caballero also dedicates a paragraph on the 'particulas Chesmantes, ojo, Vulgares' (particles which correspond with the optative 'Utinam' and other Latin forms, such as quare, quia, quoniam, etc.).

If we compare the use of Arabic terminology in the works of Caballero and Cañes with those used by Erpenius, we can conclude that the latter did not use Arabic terms so extensively. Worthy of mention are for instance: Fatha, damma, kesra in the first book 'De elementis.... We find a Latinized form of the term jazm: 'post gjezman constanter manent' 
$(1620,20)$, also used as the verb Gjezmare, gjezmant, or in the passive form gjezmatur (47), verbum hamzatum (70). The term motiones is not used as a translation of harakät but it for the change a noun undergoes if the feminine ending is added to the masculine form. ${ }^{39}$ Nunnatio is used as well (141), but the Arabic terminology for inflectional endings as used by the Spanish missionaries is not recorded.

\subsection{Possible sources}

The use of non-Western metalanguage in itself has its own tradition. Not only Pedro de Alcalá used non-Western terminology, but in Northern Europe we see also that Hebrew grammars used Hebrew terminology in an adapted form. ${ }^{40}$ Which sources could the Franciscans have used? In the prologue of the grammar, Cañes informs us that he completed an eclectic grammar in agreement with the 'taste of everyone' ("que sea del gusto de todos"), using the most useful aspects ("he procurado aprovecharme de lo bueno que en ellas he visto" ibid.) of earlier sources and adding material from his own 16 years long experience:

He procurado con el mayor cuidado y desvelo leer, y releer para el ajuste de esta, las gramaticas de Fr. Pedro de Alcalá, de Fr. Felipe Guadañoli, de Tomás Erpenio, de Fr. Antonio de Aguila, de Fr. Agapito de Valle flammarum, de Fr. Francisco Gonzalez, \& c c. Asimismo me he valido de un considerable numero de manu-scritos, que me han franqueado gustosos algunos aficionados á la lengua arabe. Finalmente he aprovechado lo que me enseñó el estudio, y la experiencia por espacio de diez y seis años, que estube predicando, y confesando en arabe en las misiones del Asia (ibid.).

I have taken the greatest care to do my best to read and read over again the grammars of Fr. Pedro de Alcalá, Fr. Philip Guadagnoli, Thomas Erpenius, Fr. Antonio de Aguila, Fr. Agapito de Valle Flammarum, and Fr. Francisco González, and others. Likewise I have used a considerable amount of manuscripts, which some 'aficionados' of the Arabic language have passed to me. Finally I have benefited from what study and experience

\footnotetext{
39 "Motio est nominis Masculini in Foemininum converse; sitque additione terminationis foemininae" (Chapter V).

${ }^{40}$ Johannes Reuchlin, who published his Hebrew grammar one year after the publication of Alcalăs, introduces the verb dagessare: "quando he uel aleph repellunt nun passiue significationis, dagessatur prima ut..." (1974 [1506] Liber III, 590). See also Geiger $(1871,129)$. The presence of Oriental elements in Western grammars is ofcourse not only present when loans are used. Translations and 'mistranslations' produced sometimes terms which are not longer recognized as from 'oriental' origin. An example is the history and development of the concept of radix (root).
} 
have taught me over the period of sixteen years that I spent predicating and confessing in Arabic in the missions of Asia.

To start with the first grammar mentioned, Pedro de Alcalás Arte, we can conclude immediately that this grammar has not been the source for the terms used for the inflectional endings. Thomas Erpenius has been apparently used, but we observed that Erpenius reduced the 'exotic' grammatical terms in his grammars, ${ }^{41}$ although he maintained them in his Latin translation of Arabic treatises written by Ibn Ājurrūm and al-Jurjānī, which could have been also the direct sources of Cañes. Ibn Ājurrūm was born in Morocco in 1273-1274 and died in Fez in 1323. $\mathrm{He}$ is the author of a grammatical compendium entitled Muqaddima al-Äjurrūmìya Mabādi' 'ilm al-'Arabī where he exposes the inflectional system of Arabic, called 'i'rāb. This treatise on syntax has been widely used until the present day and it is one of the later works 'downstream' the long tradition starting with Sibawayhi. The Muqaddima was known in Europe since the 16th century. ${ }^{42}$ This work has been printed for the first time in Europe in 1592 (Medici, Rome). A translation by Peter Kirsten (1577-1640), into Latin appeared in 1610 (Breslae, 1610), followed by a translation of Erpenius (Leidae, 1617). In 1631, another translation appeared by Thomas Obicini (1585-1632). ${ }^{43}$ The Kitāb al-'awāmil al-mia n-nahwiyya ("Book of the Hundred 'Regentia'”) of 'Abd al-Qāhir al-Jurjānī (died in ca. 1080) has been translated by Erpenius in 1617 and published together with the Muqaddima: Grammatica Arabica dicta gjarvmia \& libellus centum regentium cum versione Latina \& comentarijs (Leidae, 1617). As we shall demonstrate below, scholars in Rome, such as Philip Guadagnoli, knew this work. Erpenius used in his translations of these works 'loans' from Arabic in his specified grammatical terminology. To mention an example:

\footnotetext{
${ }^{41}$ In this article, we quote from the Rudimenta (1620). For a more complete analysis, the Grammatica Arabica, quinque libris methodice explicata a Thoma Erpenio (Leidae, 1613) and the Grammatica Arabica (Leidae, 1636) have to be taken into account.

${ }^{42}$ See his article 'Ibn Ājurrūm' (Encylopedia of Islam. New Edition, 3, 697), and Ben Cheneb (1927, 381-382).

${ }^{43}$ Thomas Obicini (1585-1632) was abbot of the Franciscan convent at Aleppo between 1613 and 1619 and in 1621 he returned to Rome where he founded the college at the St Peter Convent of Montorio where arabic was taught for the missionaries who were being prepared to spread the faith in the East. He was responsible for the supervision of the type designs of Oriental types at the Propaganda Press.
} 
partes autem eijus sunt Rafa, Nasba, Chafda and Gjezma, e quibus convenit Nominibus Rafa, nasba and Chafda, non autem Gjezma: verbis vero Rafa, nasba, and Gjezma: non autem Chafda (f. 11)

However, as has been demonstrated by Fück $(1955,68)$, Erpenius replaced in his own grammars, when possible, Arabic terminology by Latin equivalents, and his Rudimenta could not have been either the source of inspiration of Caballero and Cañes either. Erpenius maintained the Arabic terminology of the vowels:

TABLE 6 THE VOWEL SYSTEM ACCORDING TO THOMAS ERPENIUS (1636, f. 16).

\begin{tabular}{lcl}
\hline Nomen & Figura & Potestas \\
\hline Phatha $^{44}$ & $B a$ & $\begin{array}{l}\text { Nunc a purum \& clarum ut in amabam, nunc cum e mix- } \\
\text { tum, id est } \eta \text { Graecum, ut multi id nunc pronuntiant }\end{array}$ \\
Dhamma & $B u$ & $\begin{array}{l}\text { Nunc u purum \& clarum, nunc cum o mixtum, id est o ob- } \\
\text { scurum }\end{array}$ \\
Kesre & $B i$ & i simplex
\end{tabular}

Erpenius does not maintain the Arabic terms of the subclasses of the particles, as he rendered them in a Latinized form in his translation of Ibn Ājurrūm, but obviously he attempted to fit them into the Latin model. ${ }^{46}$ If we compare the translation into Latin of Erpenius with Obicini's, we can conclude that the latter also used the Arabic terms for inflectional endings. ${ }^{47}$ Obicini firstly gives the Arabic term, written in the Arabic script, then a translation is given followed by a description or paraphrase with the purpose to explain the Arabic terms: ar-raf' as 'elevatio', the definition of an-nașb is 'accusativus, quasi patiens positum sub agente' (without translation), al-xaf' is rendered as 'depressio, \& amplectitur

\footnotetext{
${ }^{44}$ In the left column the terms are also written in Arabic script, and in the second column the Arabic letter $b$ is given, together with its appropriate vocalisation.

45 "Sometimes a pure and clear $a$ as in amaba, other times mixed with an $e$ i.e. as in Greek $\eta$ as many pronounce it now," etc.

${ }^{46}$ For instance, we find definitions such as: de syntaxi Particularum: Praepositiones omnes tum separatae regunt genitivum 'fì baitin...,' instead of the terms 'nasbantes', etc. Nevertheless, in his Rudimenta we still can find verbs as "gjezmare" (1620, f. 47).

47 "Rafaa, \& Nasba, \& Chafda, \& Gezma. At nominibus ex ijs (conueniunt). Rafaa, \& Nasba, \& Chafda, non autem Gezma, Verbis verò ex eisdem, Rafaa, \& Nasba, \& Gezma, non autem autem Chafdha" (Obicini 1631, f. 3). Agapito à Valle Flemmarum has almost the same definition $(1687,194)$.
} 
genitivum, dativum, \& ablativum, quasi obliquus', and finally, al-jazm as 'abscisio, idest casus privatio, quasi à dictione cadentium scindat'. This means that Obicini decided to maintain Arabic terminology, and when explained appropriately, the learner could take advantage of these Arabic terms which were developed for describing the Arabic language.

And now let's come back to the concept of 'ämil fì. In Troupeau (1962), the most important translations in this period is listed: In Kirsten's and Obicini's translation we have 'agens', whereas the first also uses 'efficiens' and the latter uses also 'regens'. Erpenius uses both 'regens' as 'operans'. As Michael Carter observed, we see until today that the basic meaning has been neglected by many scholars:

Anderseits kann man fast an eine Verschwörung glauben, die Grundbedeutung des Terminus 'amal auch heute noch zu unterdrücken, um den unbegründeten Mythos zu verewigen, der arabische Begriff vom strukturellen Verhältnis zwischen Satzteilen sei identisch mit dem lateinischen, d.h. eine Art 'Rektion'. Daß die Grundmetapher der lateinischen 'Rektion' eine durchaus hierarchische, senkrechte Einordnung der Satzteile voraussetzt, die arabische 'amal 'Operation', aber im Gegenteil eine waagerechte Beziehung schildert, scheint die moderne Sprachwissenschaft nicht anerkennen zu wollen. (Carter 1993, 133).

Carter observed that Weiß was an exception and demonstrated that the translation by Kirsten unfortunately did not have any impact on later translations or interpretations: "Wie eine Stimme in der Wüste verbleibt noch der Aufsatz von J. Weiss. Die wörtliche und systemtreue Übersetzung operans von Kirsten hat sich leider nicht durchgesetzt" (Carter 1993, 134).

In the first place we have to add that Franciscus Martelottus and Philip Guadagnoli (1596-1656), both neglected by Troupeau, also deserve our attention in this context, since we find in their grammars of Arabic a very precise analysis and translation of the concept. To start with the latter: the concept of al-'iräb is translated as 'arabicatio' and 'amal as 'efficientia' or 'operatio', and al-'awämil as 'regentia':

Rationẽ autem, quo vnũquodque in suo vel Casu vel Modo \& quacumque dispositione locatur, quam Constructionem latini dicunt, Arabes interdum 'al-i'rāb', 'Arabicationem', proprius autem 'amalun efficientiam', seu 'operationem' appellant. Nomen autem illud, seu Verbum, seu Particula, eiusmodi operationem exercens, scilicet cuius vi aliquid in tali vel tali dispositione locatur, dicitur, 'āmilun' 'operans', 'regens'. Locatum verò ex eius dicitur 'ma'mūlun operatum', 'rectum'. Exinde dicuntur, 'al-'awāmilu regentia'. Quibus omnibus notis, nihil superest Grammatico. Collegit autem quidam, 
cognomine Giargianius, in libello Regentia omnia, quem propterea nominavit 'De Centum Regentibus'. Regentia enim, vel sunt 'lafziyya ${ }^{\text {tun }}$ explicita', vel 'ma'nawiyyat ${ }^{\text {tun }}$ implicita'. ${ }^{48}$ (Guadagnoli 1642, f. 248).

However, the system according to which a constituent has to be placed in the appropriate case or mode and on which convenient position has to be placed, this system which the speakers of Latin call 'Constructio' [= syntax], is system is called $a$-' $^{\prime}{ }^{\prime} r a \bar{b} b$ by the Arabs which means 'arabicization', but they call this more appropriately 'amal ${ }^{\text {n ' }}$ 'efficiens' [an act which produces a certain effect], or 'operation' [an act caused by force of an 'operator']. When a Noun, a Verb or a Particle produces such effects in this manner, and when by force of this effect something has to be placed in a certain disposition, we call this 'āmil ${ }^{u n}$ ['producing a certain effect upon something,' 'to govern']. The element which has been effected is called $m a^{\prime} m \bar{u} l^{u n}$ ['the governed']. Consequently, al-'awāmilu are called regentia ['governers']. Although all this is well-known, nothing has been transmitted by 'The Grammarian',9 but someone with the name Giargianius has collected in a booklet all the 'regentia', which can be subdivided in two subclasses, the lafziyya ('expressed') and the ma'näwiyya ('abstract').

As we see, Guadagnoli's description is not only accurate and complete, since the original Arabic is given and the literarly meaning had been maintained, but he also mentions his source, which is the hundred 'regentia' written by al-Jurjānī ('Giargianius'). ${ }^{50}$

Do we find traces of these translations of 'amal other grammars written in Latin of this period? The answer is positive. In chronological order we shall summarize what other grammarians from Rome taught us, starting with one of the earlier grammars that appeared in Rome after the Medici translation of the work of Ibn Ājurrūm, the Institutiones of Franciscus Martelottus.

Martelottus not only mentions Erpenius in his prologue $(1620,38),{ }^{51}$ but he also deals with methodology. Should the Arabic model with

\footnotetext{
48 'Operators' can be 'expressed' (lafziyy), and 'abstract' (ma'nawī). "The first class are the particles or verbs or nouns that are either actually uttered or elided but understood, while the latter are abstract causes that do not involve uttered or restored linguistic elelements." (Baalbaki 2004, XV, 23-58). This means that elided elements can produce 'effects.'

${ }_{49}$ We could not identify this 'Grammarian.'

${ }^{50}$ Also in other paragraphs we see direct translations in the work of Guadagnoli, which remain close to the Arabic original, such as 'ignoratum, for majhül, usually erroneaously translated as 'passive, opposed to 'cognitum' for the 'active' (ma'rüf) (Guadagnoli, 1642, f. 255).

51 "Scripsit autem eleganter admodum de dictionibus hisce, quemadmodum \& de litteris eruditissimus Orientalium linguarum in Leidensi Academia professor Thomas Erpenius uniusquam leuasset quoq. nobis huiis secundi libri labores partem" $(1620,38)$.
} 
its technical terms be maintained, or should they be abandoned and replaced by Latin terminology? Martelottus decided to follow the traditional method when dealing with the single word classes ("Priora vero hic loci propriè de singulis dictionibus singillatim ordine debito, ac recta methodo explicanda sunt" $(1620,37)$, but we can infer from his preface, he obviously follows the Arabic model, and he does this explicitly. ${ }^{52}$ However, Martelottus does not leave the Arabic terminology out of his volume:

Ubi omisso Arabicorum grammaticorum ordine Latinis admodum dissono, in rebus pluribus nobiscum, quoad methodum conuenisse comperimus. Caeterum quamvis à praedicta Arabum methodo deflectentes, nostro nos ordine Latinis magis consono procedamus, omnino grammaticalibus vocibus ubique utemur, eorumque ordines, ac procedendi rationes, divissiones, ac series enucleabimus, ut faciliro cunctis ad eosdem perlegendos authores pateat aditus. (Martelottus 1620, 38).

Whenever the difference between Arabic grammars and the Latin way of construction was left out of consideration, we discovered that, with respect to the system of the language, Arab had many similarities with ours. After all, to what extent we ourselves may differ from this language system of the Arabs and are differing more and more as well from the Latin way of construction, we should still use in our research the Arab terminology and developing our knowledge we will explain the systems, the methods of construction and concatenation, in order to make it easier for us all to read the same authors.

Martelottus's methodology is in our eyes extremely modern. It tries to bridge the gap between 'exo- and endo-grammaticalization.' An eclectic approach, combining the best elements of both traditions and their corresponding technical terms is the best way to understand the Arabic language. Martelottus also dedicates an entire chapter to inflection (" $D e$ 'i'rāb, seu Inflexione"), translated as 'Arabificatio', or 'Arabicatio' (1620, 98). The concept of 'ämil is translated again as 'operans' and the author quotes directly from the Arabic grammatical tradition:

'i'rāb' apud Grãmaticos 'tag்yīru awākhir al-kalām ilā al-ikhtilāf al'awāmil:' variatio ultimorum, seu extremitatum dictionum, ob diversitatem operantium $(1620,98)$.

${ }^{52}$ In his grammar we find Arabic terminology extensively, together with the Latinized form, for instance the traditional Arabic classification of the consonants: "Chalchiiton, lahuiiaton, sciagiariiaton, asliiaton, natiiaton, dhalchiiaton, sciaphahiiaton, liniiaton" $(1620,35)$. 
Variation of the final parts or extremities of the words, caused by the diversity of the operators ('by the different effects produced by the operators').

At the end of the 17th century, Agapito à Valle Flemmarum treats the particles in detail in his chapter entitled "De syntaxi Particularum," and particularly describes the 'effect' they have as 'operators' on the inflectional system, translating al-ḥurūf al-'àmila as:

1. "particlae 'operantes' in nomen simplex Giarrantes,

2. et in nomen simplex nasbantes,

3. et in summam,

4. et in verbum nasbantes,

5. et 'operantes' in verbum Giezmantes"' $(1687,268)$.

Another Franciscan, Antonio ab Aquila, also used Arabic terminology for the particles, although we do not find the same definitions. In his classification of the subclasses, we find a Latin terminology, such as 'particulae coniunctae' and 'particulae separatae', with subclasses, such as 'particula interrogationis, iurandi, status in loco, ad determinationem, optativi, conformandi, negationis, conditionalis' (1650, Caput XXV, 388 ff.). However, he also uses Arabic terms, such as 'particula Giàzemeh' (f. 403).

And finally, the question rises wether we find traces of the concept of 'amil in the two Spanish grammars. The answer is again positive, as we shall demonstrate. Lucas Caballero gives rules for classical Arabic ('gramática literal') where particles have a certain 'effects':

De las particulas charrantes

Despues de las particulas que hemos puesto en el Arabo corresponden a nuestras quatro ultimas partes de la oracion, de las quales particulas, la mayor parte son literales; siguiendo el intento de dar algunas reglas de la grammatica literal, quiero explicar algunos efectos que tienen las particulas puestas o otras que a ellas siguen... (Cabellero 1709, f. 7r.; emphasis is mine)

After the particles we have put in Arabic, four final parts of speech correspond with ours, whose major part are literary utterances: following our intention to give some rules of literary grammar, I want to explain certain effects these particles have when placed, or other which follow after them.

In the grammar of Cañes, we find exactly the same term, hispanicised as 'operacion:' 
... quando se les une la particula mā quedan absolutamente privadas de su operacion, y regimen, de suerte que pierden la fuerza que tenian de colocar el sujeto en el caso 'nasbo' y se queda en el 'rafeo', ó nominativo, como ciertamente que escrivir á Pedro, 'innamā sayaktubu Butrus' (Cañes 1775, 144; emphasis is mine).

... when combined with the particle $m a \bar{a}$ they remain absolutely deprived of their 'operation' and 'government' so that they loose their force which they had before to put the nassb ( $a$ inflection, or direct object) and it remains in the raf' ( $u$ ending, or subject) or nominative, as in 'certainly to write to Peter' 'innamà sayaktubu Batrus'.

To sum up, we have found the following authors as possible sources of the two Franciscan grammarians of Damascene Arabic: Ibn Ājurrūm and al-Jurjānī (through translations of the Medici edition, Erpenius, Obicini and maybe also Kirsten) as the main Eastern sources. Western sources mentioned by name are Erpenius, Golius (mentioned by Cañes), Agapito à Valle and Guadagnoli. It has to be observed that missionary grammarians in Rome were familiar with some of the most important Arabic authors. The name of Al-Xalīl b. Ahmad al Farāhidī (died in 780) who codified and established a system of 15 meters has been mentioned by Guadagnoli. Since the grammars of Caballero and Cañes do not have a final chapter on prosody, they did not deel the need to use this source. Another prominent pioneer, who established the 'foundations' of Arabic grammar is of course Sibawayhi, whose work became known in the West through translations of Jahn. It is surprising that we find already in 1620 his name in the grammar of Martelottus, which is evidence for the fact that missionary-grammarians in Rome knew who he was. Dealing with the 'verba ternaria,' Martelottus explains that the 'forma masdari' is irregular, and in that context he mentions Sibawayhi:

In verbis ternarijs, ut iam diximus, forma masdari irregularis est, omnes autem quidem Author Arabicus, nomine Sibauai ad 32. reuocauit, videlicet (1620, 213).

In the ternary verbs, as we said before, the masdar-form is irregular; indeed, the Arabic author with the name Sibawayhi reduced all these to 32.

The same author, Martelottus, also mentions another Arabic source in his chapter dealing with the 'Constructio Particularum' where he divides the 'particulas operantes' in five subclasses, in agreement with an Arabic work called Lucerna, or Al-Mişbāh, the "particulae operantes in nomen simplex giarrãtes, particulae operantes in nomen simplex nesbantes, in verbum nasbantes, in verbum gezmantes," and the original text in 
Arabic script is given in the same table as well. Although Martelottus does not give the name of the author, we think this work is probably the treatise written by al-Muțarrizī, entitled Al-Mișbāh fì 'ilm an-nahw. Al-Mutarrizi (1144-1213) compiled this treatise which became a textbook in the madrasas of the East. The Mișbāh itself wa sbased on three small grammatical monographs of al-Jurjānī (Lichtenstädter 1936, 847 and Sellheim (EI [New edition] 7, 773).

\section{Conclusion}

Summarizing, we can conclude that Pedro de Alcalás use of Arabic terminology seems to be unsystematic and the reasons why he used them remain unclear, particularly when he uses the Arabic names for the cases. They do not reflect the Arabic inflectional endings and his model was obviously Latin grammar. The use of the term damir is an exception, since the suffixed pronouns can be used in a different wayattached to verbs, nouns and particles-compared to Latin. Pedro de Alcalás mnemonic terms of the vowels stand alone, and we do not find any use of them in other works and in his dictionary we do not find the terms fatha, kasra, and damma. Although we find in Alcalás dictionary the translation 'obrar' for the Arabic root 'amala there are no traces of Arabic theory concerning 'operators' or 'government', related to this term.

The earliest translations of al-Jurjānī and Ibn Ājurrūm are without any doubt an important milestone for the development of the study of nonWestern grammatical theory in the West and probably for some of them a real new 'discovery', which can serve as an enrichment of the Western system, as Martelottus postulates. Direct influence of these works can be found in the grammars of Martelottus, Ab Aquila, Agapito and Guadagnoli, and the Franciscans in Damascus continued this tradition. Although Caballero and Cañes were not the pioneers themselves, they were probably the first grammarians who introduced extensively Arabic terminology in the Spanish metalanguage, as we have demonstrated.

In Northern Europe, however, we see a different approach. Erpenius did not aim at orientalising Western grammatical terminology, except for the terms for the vowels and some other terms. The concept of 'âmil has followed its own course in grammatical theory and in the 20th century it was absorbed by anachronistic terms such as 'government' and 'dependency', as Carter demonstrated. Nevertheless, we have 
demonstrated that the Franciscans were totally aware of the right connotations of 'ämil although we have to admit that sometimes they use 'gobierno' or 'regimen' as a synonym for 'efficiens' or 'operans.' Guadagnoli and Martelottus gave us without any doubt the most detailed analysis, and probably Caballero and Cañes have been inspired by their works. It was surprising that not only works of Ibn Ājurrūm, al-Jurjānī and al-Mutarrizi are mentioned by name by some of the grammarians working in Rome, but even Sibawayhi is mentioned by name in this relatively early period (1620).

Missionary linguistics in Rome, particularly the achievements of scholars and teachers who published grammars in the seventeenth century at the Polyglot Press of the Sacra Congregatio de Propaganda Fide deserve to be studied more in detail in future. Particularly those authors who tried to combine exo- and endo-grammatical terminology and approaches have been innovative. How the learners of Arabic appreciated this 'bridging' approach is another question. Many scholars preferred in their teaching curriculum the more Latin-based grammar of Erpenius and his work was without any doubt a great success during many centuries. However, I agree with Martelottus that there is no reason to postulate that the Arabs differ from our system. We can also say, "we ourselves may differ from this Arabic language system." While using their own terminology, which has been developed for their own linguistic phenomena, we will make progress in the understanding of not only the language but of the linguistic model as well.

\section{References}

\subsection{Primary sources}

Alcalá, Pedro de. [Before 5 Feb. 1505a]. Arte para ligeramente saber la lengua arauiga. Salamanca: Juan Varela.

- [Before 5 Feb. 1505b]. Vocabulista arauigo en letra castellana. Salamanca: Juan Varela.

- . [ca. 1506a]. Arte para ligera mente saber la lengua arauiga emendada y añadida y Segunda mente imprimida. Salamanca: Juan Varela.

- . [ca. 1506b]. Vocabulista arauigo en letra castellana. Salamanca: Juan Varela. [Biblioteca Nacional, R 31638.] Re-edition: Paul de Lagarde. 1883. Petri Hispani de lingua arabica libri duo. Gottingae: In aedibus Dieterichianis Arnoldi Hoyer. Reprint: Osnabrück: Otto Zeller, 1971.

Aquila, Antonio Ab. 1650. Arabicae linguae novae, et methodicae institutiones. Non ad vulgaris dumtaxat Idiomatis; sed etiam ad Grammaticae doctrinalis intelligentiam, per Annotationes in Capitum Appendicibus suffixas, accomodatae. Authore F. Antonio ab Aquila Or. Min. Sancti Francisci strict. Obser. Theologo, atque in Collegio Sancti Petri 
Martis Aurei à Sacra Congregatione de propaganda Fide Arabicae linguae deputato lectore. Opus tum omnibus Arabicae linguae studiosis, tum potissumum Apostolicis Viris, per Asiam \& Africam Fidem propagaturis, utile \& necessarium. Romae: Typis Sac. Cong. De Prop. Fide.

Caballero, Lucas. [Cauallero] 1709. Compendio de los Rudimentos y Gramatica Araba en que se da suficiente notizia de la lengua Vernacula o Vulgar y algunas Reglas de la literal Iustamente P.M.R.F. Bernardino Gonzalez hijo de la Proâ de la Concepzion en España Lector Jubilado en Arabo y Misionero Apostolico del Oriente y recoplada por el Re. ${ }^{d o} P$. Fr. — Mo Apostolico hijo de la Proa de los Angeles Lector actual Arabo en el colegio de Damasco. Ms. Rogge Library, Handskriftssamlingen, Sweden.

Cañes, Francisco. 1775. Gramatica arabigoespañola, vulgar, y literal. Con un diccionario arabigo-español, en que se ponen las voces mas usuales para una conversacion familiar, con el Texto de la Doctrina Cristiana en el idioma arabigo. Madrid: En la Imprenta de Don Antonio Perez de Soto.

Dombay, Franciscus de. 1800. Grammatica linguae Mauro-Arabicae juxta vernaculi idiomatic usum, accessit vocabularium Latino-Arabicum. Vindobonae: apud Camesina.

Erpenius, Thomas. 1617. Grammatica Arabica dicta Gjarumia, \& Libellus centum regentium cum versione latina \& commentariis Thomae Erpenii. Leidae: Ex typographia Erpeniana Linguarum Orientalium.

- 1620. Rudimenta lingvo arabicae. Accedunt ejusdem Praxis Grammatica; \& Consilium de studio Arabico feliciter instituendo. Leidae: Ex Typographia Auctoris.

Germanus [of Silesia], Dominicus. 1639. Fabrica linguae Arabicae cum interpretatione Latina \& italica, accomodata ad usum linguae vulgaris, \& scripturalis. Romae: Typis Sac. Congreg. De Prop. Fide.

—. 1640. Fabrica Arabica copiosioribus impensis atque vberiori structura. Romae.

González, Bernardino 2005 [c. 1705]. Intérprete Arábico. Edición y estudio preliminar por Ramón Lourido Díaz. 2 vols. Madrid: Real Academia de la Historia/Ministerio de Asuntos Exteriores y de Cooperación.

— 2005 [c. 1705]. Epítome de la gramática arábiga. Edición y estudio preliminar por Ramón Lourido Díaz. 2 vols. Madrid: Real Academia de la Historia / Ministerio de Asuntos Exteriores y de Cooperación.

Guadagnoli, Philippi. 1642. Breves Arabicae linguae Institutiones. Romae: Ex Typographia Sac. Congregationis de Propaganda Fide.

Martelottus (= Martelotti), Franciscus. 1620. Institutiones Linguae Arabicae Tribus Libris distributae. In quibus uberrime quaecumque ad litteras, Dictiones \& Orationem attinent, explicantur. Authore P. Francisco Martelotto Martinensi, Sacerdote, Theologo, Clericorum Regularium Minorum. Romae: Excudebat Stepahsnus Paulinus.

Nepos, Ferdinandus. 2000.[c. 1468-1485]. Materies. (Ms. See Codoñer).

Obicini, Franciscus. 1631. Grammatica Arabica Agrumia appellate. Cum versione Latina ac dilucida expositione. Adm. R.P.F. Thomae Obicini Noniensis, Diae. Nouariau, ord. Minorum Theologi, ac linguarum Orientalium in Collegio S. Petri Montis Aurei, de mandato Sacrae Congregationis Fidei propaganda Magistri. Romae: Typis Sac. Congregationis de Propaganda Fide.

Oyanguren de Santa Inés, Melchor. 1738. Arte de la lengua japona. Dividido en quatro libros segun el Arte de Nebrixa, con algunas voces proprias de la escritura, y otras de los lenguages de Ximo, y del Cami, y con algunas perifrasis, y figuras. México: Joseph Bernardo de Hogal.

—. 1742. Tagalysmo elucidado, y reducido (en lo possible) â la Latinidad de Nebrija, con su Syntaxis, Tropos, Prosodia, Passiones, \&c. y con la allusion, que en su uso, y composicion tiene con el Dialecto Chinico Mandarin, con las Lenguas Hebrea, y Griega. México: D. Francisco Xavier Sánchez, en la Calle de San Francisco.

Reuchlin, Johannes. 1974[1506]. De rudimentis hebraicis libri III. Pforzheim. Reprint: Hildesheim - New York: Georg Olms Verlag.

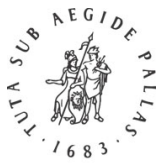


Rodrigues, Ioão. (Rodriguez) 1604-1608. Arte da Lingoa de Iapam composta pello Padre — Portugues da Copanhia de Iesv diuidida em tres Livros. Com Licença do Ordinario, e Svperiores. Nagasaqui: no Collegio de Iapão da Companhia de Iesv Anno. 1604 (-1608 - colofon.)

Rodrigves, Ioam. 1620. Arte Breve da Lingoa Iapoa tirada da Arte Grande da mesma lingoa, pera os que comecam a aprender os primeiros principios della. Pello Padre Ioam Rodrigvez da Companhia de Iesv Portugues do Bispado de Lamego. Diuidida em tres Livros. Com Licenca do Ordinario, \& Superiores. Amacao: no Collegio da Madre de Deos da Companhia de Iesv.

Roth, Heinrich. 1988[ca. 1662]. Grammatica Linguae Sanscretanae Brachmanum Indiae Orientalis. Facsimile edition: Arnulf Camps \& Jean-Claude Muller: The Sanskrit Grammar and Manuscripts of Father Heinrich Roth S.J. (1620-1668). Facsimile edition of Biblioteca Nazionale, Rome, Mss.Or. 171 and 172. Leiden: E. J. Brill.

Valle Flemmarum, Agapiti à. 1687. Flores Grammaticales arabici idiomatis collecti ex optimis quibusque Grammaticis nec non pluribus Arabum monumentis, ad quam maximam fieri potuit brevitatem atque ordinem revocati: Studio, \& Labore Fr. Agapiti à Valle Flemmarum Ordinis Minorum S. Francisci reformatorum Provinciae Tridentinae, in Semionario Patavino lectoris. Opus omnibus Arabicae Linguae Studiosis perutile, \& necessarium. Patavii: Ex Typographia Seminarii Opera Augustini Candiani.

Ziegenbalg, Bartholomäus. 1985 [1716]. Grammatica Damulica. Quœe Per Varia Paradigmata, Regulas \& Necessarium Vocabulorum Apparatum, Viam Brevissimam Monstrat, Qua Lingua Damulica Seu Malabarica, Qua Inter Indos Orientales in Usu Est, \& Hucusque In Europa Incognita Fuit, Facile Disci Possit: In Usum Eorum Qui Hoc Tempore Gentes Illas Ab Idololatria Ad Cultum Veri Dei, Salutemque Aternam Evangelio Christi Perducere Cupiunt... Halæ Saxonum: Litteris \& Impensis Orphanotrophei. Ed. Burchard Brentjes \& Karl Gallus, Halle: Martin-Luther-Universität Halle-Wittenberg, 1985.

\subsection{Secondary sources}

Baalbaki, Ramzi. 2004. Grammarians and Grammatical Theory in the Medieval Arabic Tradition. Aldershot: Ashgate -Variorum.

Ben Cheneb, Mohammed 1927. "Ibn Ādjurrūm.” Enzyklopädie des Islām. 2.381-382. Leiden - Leipzig: Brill - Harrassowitz.

BICRES (see Niederehe).

Carter, Michael G. 1991. "Review Owens 1988." Journal of the American Oriental Society, 111.2: 395-397.

_. 1993. "Probleme bei der Übersetzung von Fachsprache am Beispiel des Arabischen." In Frank, Armin Paul, Kurt-Jürgen Maaß, Fritz Paul, und Horst Turk, eds. Übersetzen, Verstehen, Brücken bauen. Geisteswissenschaftliches und literarisches Übersetzen im internationalen Kulturaustausch. Berlin: Erich Schmidt., 1.130-141. _. 1994. "Review Owens 1990". Journal of the American Oriental Society, 114.3: 472475.

Codoñer, Carmen. 2000. Gramáticas Latinas de transición. Juan de Pastrana, Fernando Nepote. Introducción y edición crítica. Salamanca: Ediciones Universidad de Salamanca.

Corriente, Federico. 1988. El léxico árabe andalusí según P. de Alcalá. (Ordenado por raíces, corregido, anotado y fonémicamente interpretado. Madrid: Universidad Complutense de Madrid.

Cowan, William. 1981. "Arabic grammatical terminology in Pedro de Alcalá." Historiographia Linguistica, 8.2/3:357-363.

Dannenfeldt, Karl H. 1955. "The Renaissance Humanists and the Knowledge of Arabic." Studies in the Renaissance, 2, 96-117.

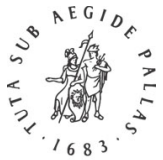


Escavy, R., M. Hernández Terrés, A. Roldán, eds. 1994. Actas del Congreso Internacional de Historiografía Lingüística. Nebrija V-Centenario 1492-1992. Murcia, 1-4 abril 1992. Murcia: El Taller, vol. III: Nebrija y otros temas de historiografía lingüística.

Frank, Armin Paul, Kurt-Jürgen Maßß, Fritz Paul, und Horst Turk, eds. 1993. Übersetzen, Verstehen, Brücken bauen. Geisteswissenschaftliches und literarisches Übersetzen im internationalen Kulturaustausch. Berlin: Erich Schmidt.

Fück, Johann. 1955. Die arabischen Studien in Europa bis in den Anfang des 20. Jahrhunderts. Leipzig: Otto Harrassowitz.

Geiger, Ludwig. 1871. Johann Reuchlin. Sein Leben und seine Werke. Leipzig: Duncker and Humblot.

Hauschild, Richard. 1988. 'Notes on the Content of the Three Manuscripts of Heinrich Roth.' Arnulf Camps and Jean-Claude Muller: The Sanskrit Grammar and Manuscripts of Father Heinrich Roth S.J. (1620-1668). Facsimile edition of Biblioteca Nazionale, Rome, Mss.Or. 171 and 172. Leiden: E.J. Brill.

James, Gregory. 2007. "The terminology of declension in Early Missionary Grammars of Tamil." In Zwartjes, Otto, Gregory James and Emilio Ridruejo, eds., Missionary Linguistics III/Lingüística misionera III. Morphology and Syntax. Selected papers from the IIIrd and IVth International Conferences on Missionary Linguistics, Hong Kong/ Macau/Valladolid, 167-190.

Juynboll, W.M.C. 1931. Zeventiende-eeuwsche beoefenaars van het Arabisch in Nederland. Utrecht: Kemink en Zoon.

Kerkhof, Maxim, Hugo de Schepper, Otto Zwartjes, eds. 1993 España: ¿Ruptura 1492?. Amsterdam: Rodopi.

Killean, Carolyn G. 1984. “The development of Western Grammars of Arabic.” Journal of Near Eastern Studies, 43.3: 223-230.

Law, Vivian. 2002. The History of Linguistics in Europe. From Plato to 1600. Cambridge: Cambridge University Press.

Lentin, Jerome. 1997. Recherches sur l'histoire de la langue arabe au Proche-Orient à l'époque moderne. Thèse de Doctorat d'État, Université de Paris III.

Lichtenstädter, Ilse. “Al-Muțarrizī.” Enzyklopädie des Islām, 3:847. Also New edition: R. Sellheim, 7:773.

Lourido Díaz, Ramón. 2005. “Estudio preliminar”. See: González (primary sources).

Maruyama, Toru. 2004. "Linguistic Studies by Portuguese Jesuits in Sixteenth and Seventeenth Century Japan." In Zwartjes, Otto and Even Hovdhaugen, eds. Missionary Linguistics [I]/Lingüística misionera [I]. Selected papers from the First International Conference on Missionary Linguistics, Oslo, 13-16 March 2003. Amsterdam: John Benjamins. 141-160.

Monroe, James. T. 1970. Islam and the Arabs in Spanish Scholarship (Sixteenth century to the present). Leiden: Brill.

Mörner, A.R. and Magnus Mörner. 2001. Spanien i svenska arkiv. Skrifter utgivna av Riksarkivet, 16. Stockholm: Riksarkiv, 60-61.

Niederehe, Hans-Josef. 2005. Bibliografía cronológica de la lingüística, la gramática y la lexicografía del español (BICRES III). Desde el año 1701 hasta el año 1800. Amsterdam: John Benjamins.

Owens, Jonathan. 1988. The Foundations of Grammar. An introduction to Medieval Arabic Grammatical Theory. Amsterdam: John Benjamins.

- 1990. Early Arabic Grammatical Theory. Heterogeneity and Standardization. Amsterdam: John Benjamins.

Schnurrer, Christianus Fridericus de. 1811. Bibliotheca Arabica. Halae ad Salam: I.C. Hendelii.

Smith-Stark, Thomas. 2005. “Phonological description in New Spain.” In Zwartjes, Otto and Cristina Altman, eds.. Missionary Linguistics II/Lingüística misionera II. Orthography and Phonology. Selected Papers from the Second International Conference on Missionary Linguistics, São Paulo, 10-13 March 2004. Amsterdam: John Benjamins, $1-64$.

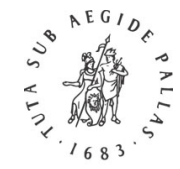


Troupeau, G. 1962. “Trois traductions latines de la 'Muqaddima' d’Ibn Āğurrūm.” Études d'Orientalisme dédiées á la mémoire de Lévi-Provençal. Paris: Maisonneuve et Larose, $1.359-365$.

Versteegh, Kees. 1997. Landmarks in Linguistic Thought III. The Arabic Linguistic Tradition. London: Routledge.

Weiß, Josef. 1910. "Die Arabische Nationalgrammatik und die Lateiner." Zeitschrift der deutschen Morgenländischen Gesellschaft, 64:349-390.

Zwartjes, Otto. 1993. "El artículo en las gramáticas pioneras de Nebrija y Alcalá y las gramáticas grecolatinas." In Kerkhof, Maxim, Hugo de Schepper, Otto Zwartjes, eds. España: ¿Ruptura 1492?. Amsterdam: Rodopi, 261-286.

- 1994. "Tradición e innovación en las gramáticas pioneras de Antonio de Nebrija y Pedro de Alcalá: la categoría gramatical del pronombre." In Escavy, R., M. Hernández Terrés, A. Roldán, eds. 1994. Actas del Congreso Internacional de Historiografía Lingüística. Nebrija V-Centenario 1492-1992. Murcia, 1-4 abril 1992. Murcia: El Taller, 3:651-665.

- 2007. "Agreement asymmetry in Arabic according to Spanish missionary grammarians from Damascus (XVIIIth century)." In Zwartjes, James, Ridruejo, eds., forthcoming. Missionary Linguistics III/Lingüística misionera III. Morphology and Syntax. Selected papers from the IIIrd and IVth International Conferences on Missionary Linguistics, Hong Kong/ Macau/Valladolid, 273-303.

, and Even Hovdhaugen, eds. 2004. Missionary Linguistics [I]/Lingüística misionera [I]. Selected papers from the First International Conference on Missionary Linguistics, Oslo, 13-16 March 2003. Amsterdam: John Benjamins.

- and Cristina Altman, eds. 2005. Missionary Linguistics II/Lingüistica misionera II. Orthography and Phonology. Selected Papers from the Second International Conference on Missionary Linguistics, São Paulo, 10-13 March 2004. Amsterdam: John Benjamins.

_, Gregory James and Emilio Ridruejo, eds. 2007. Missionary Linguistics III/Lingüística misionera III. Morphology and Syntax. Selected papers from the IIIrd and IVth International Conferences on Missionary Linguistics, Hong Kong/ Macau 12-15 March 2005. Valladolid, 8-11 March 2006. Amsterdam: J. Benjamins. 